\title{
Global transcriptional response of pig brain and lung to natural infection by Pseudorabies virus
}

\author{
JF Yuan ${ }^{\dagger 1,2,3}$, SJ Zhang ${ }^{\dagger 1,2}$, O Jafer ${ }^{2}$, RA Furlong2 ${ }^{2}$ OE Chausiaux ${ }^{2}$, CA Sargent ${ }^{2}$, \\ GH Zhang ${ }^{3}$ and NA Affara*2
}

\begin{abstract}
Address: ${ }^{1}$ Key Lab of Agricultural Animal Genetics, Breeding and Reproduction of Ministry of Education, HuaZhong Agricultural University, 430070, PR China, ${ }^{2}$ Department of Pathology, University of Cambridge, Cambridge CB2,1QP, UK and ${ }^{3}$ College of Veterinary, South China Agricultural University, 510642, PR China

Email: JF Yuan - yuanjinfeng@scau.edu.cn; SJ Zhang - sjxiaozhang@mail.hzau.edu.cn; O Jafer - ojafer@mbg.ae; RA Furlong - robf17@hotmail.com; OE Chausiaux - oriane@temperatureconcepts.com; CA Sargent - cas1001@cam.ac.uk; GH Zhang - guihongzh@scau.edu.cn; NA Affara* - na@mole.bio.cam.ac.uk

* Corresponding author †Equal contributors
\end{abstract}

Published: I December 2009

BMC Microbiology 2009, 9:246 doi:10.1 |86/147/-2180-9-246
Received: 17 March 2009

Accepted: I December 2009

This article is available from: http://www.biomedcentral.com/I47I-2180/9/246

(C) 2009 Yuan et al; licensee BioMed Central Ltd.

This is an Open Access article distributed under the terms of the Creative Commons Attribution License (http://creativecommons.org/licenses/by/2.0), which permits unrestricted use, distribution, and reproduction in any medium, provided the original work is properly cited.

\begin{abstract}
Background: Pseudorabies virus (PRV) is an alphaherpesviruses whose native host is pig. PRV infection mainly causes signs of central nervous system disorder in young pigs, and respiratory system diseases in the adult.

Results: In this report, we have analyzed native host (piglets) gene expression changes in response to acute pseudorabies virus infection of the brain and lung using a printed human oligonucleotide gene set from Illumina. A total of 210 and I I 30 out of 23,000 transcript probes displayed differential expression respectively in the brain and lung in piglets after PRV infection ( $P$-value $<0.01$ ), with most genes displaying up-regulation. Biological process and pathways analysis showed that most of the up-regulated genes are involved in cell differentiation, neurodegenerative disorders, the nervous system and immune responses in the infected brain whereas apoptosis, cell cycle control, and the mTOR signaling pathway genes were prevalent in the infected lung. Additionally, a number of differentially expressed genes were found to map in or close to quantitative trait loci for resistance/susceptibility to pseudorabies virus in piglets.
\end{abstract}

Conclusion: This is the first comprehensive analysis of the global transcriptional response of the native host to acute alphaherpesvirus infection. The differentially regulated genes reported here are likely to be of interest for the further study and understanding of host viral gene interactions.

\section{Background}

Pseudorabies virus (PRV), is a member of the alphaherpesvirus subfamily and has multiple closely related family members, such as the herpes simplex virus1 (HSV-1), varicellovirus (VZV), avian herpes viruses, bovine herpesviruses (BHV-1), equine herpesviruses (EHV-1 and EHV-4), feline herpesvirus type 1 and canine herpesvirus type
$[1,2]$. Thus PRV has served as a useful model organism for the study of herpesvirus biology[1]. Owing to its remarkable propensity to infect synaptically connected neurons, PRV is also studied as a "live" tracer of neuronal pathways[1]. Finally, while vaccination strategies to eradicate PRV in the United States and Europe have shown great progress, they fail to eradicate completely viral infection 
from a population. Thus outbreaks in swine populations result in substantial economic losses. These include restrictions on animal movement and trade for affected countries, with disease and infection control measures increasing production costs owing to antibody testing, vaccination programs and extra labor.

Although PRV has been widely studied (especially its agricultural impact, its viral pathogenesis, its molecular biology, its use as a neuronal tracer, and in DNA vaccine exploration [1]) how the native host responds globally after infection with wild type PRV is still poorly understood. Clinically, infection in older pigs ranges from asymptomatic to severe respiratory disease but with limited mortality. Young piglets exhibit more serious clinical signs and often succumb to fatal encephalitis preceded by typical behaviors consistent with infection of the central nervous system. In recent years, microarray technology has proven useful to assess the cellular transcriptional responses to herpesvirus infections in human and mouse cell lines [3-5]. It has been used to study host gene expression after PRV infection of rat embryo fibroblasts [5], and the central nervous system (CNS) in rodent brain at various times post infection in vivo [6]. However few porcine genome-wide expression studies have been published. Most experiments have used 'in-house' cDNA arrays to study transcriptional events in pig tissues, such as the stress-genes related to early weaning of piglets [7]. The down side of these cDNA-based clone libraries is that the genes represented on the array are often very focused on a given biological system or process and lack a whole genome overview.

In this study, piglet samples were hybridized onto an Illumina Human Refset Chip (Illumina Inc. San Diego), corresponding to 23,000 transcript probes. This cross-species comparison potentially allows the study of the whole transcriptome. There are now porcine arrays available from commercial suppliers (e.g. Affymetrix and Qiagen), but these are not all representative of the entire pig genome and were not widely available at the time of this study. In the absence of a comprehensive species-specific array deeper interrogation of the pig gene complement was afforded by the use of the better annotated human geneset. Although the use of this approach can only be partially informative when there are no confirmed pig orthologues in the public databases, we have identified host cellular genes whose mRNA levels change during natural PRV infection of piglet brain and lung. The resulting data define key pathways of host-gene expression that characterize the host response to an acute central nervous system (CNS) and respiratory infection.

\section{Methods \\ Experimental pigs and housing}

The experimental animals were sourced from an outbreak of PRV that occurred in the farrowing house of a local commercial farmer due to a reduced level of protection via maternal antibody. Clinical signs were described as follows: suckling piglets were listless, febrile, and uninterested in nursing. Within $24 \mathrm{~h}$ of exhibiting these clinical signs, some piglets progressively developed indications of central nervous system infection including trembling, excessive salivation, lack of coordination, ataxia, and seizures. Infected piglets sat on their haunches in a "doglike" position, lay recumbent and paddled, or walked in circles. The appearance of the dissected organs in selected piglets was typical of PRV infection: bleeding in meninges, oedema in the brain, bleeding spots in the lung and on the adenoids $[1,8]$.

Three strict criteria were imposed for the selection of piglets included in this study: 1) piglets exhibited the typical clinical signs described above; 2) piglets exhibited the expected pathology, especially in brain and lung; 3) virus isolation, antibody identification or detection of viral antigen-positive tissues were used to confirm the organic infection by PRV, and diseases including Swine Fever (SF), Porcine Reproductive and Respiratory Syndrome Virus (PRRSV) and other potential bacterial infections which could be clinically and pathologically confused with PRV infection were excluded by viral antigen, antibody identification and PCR detection.

Six piglets aged from 2 to 4 days (commercial breed Landrace X Yorkshire) which were infected by PRV but not by the other tested diseases (see above) and 3 healthy piglets (not infected, and negative for all tests under the strict criteria used above), matched for age and breed from the same farm were used in this experiment. All experiments were carried out in strict accordance with accepted HuaZhong Agricultural University, China and governmental policies.

\section{Microarray experimental design}

Total mRNA samples from the brains and lungs of the 3 normal piglets were pooled for the reference mRNA. Ten independent RNA samples ( 6 biological replicates for brain and 4 biological replicates of lung) from the 6 infected piglets were paired with the reference sample for hybridization on two-color microarrays. Using a dye-swap configuration, comparing each sample provides technical replicates to adjust for dye bias[9]. A total of 20 slides were used in this study.

\section{RNA purification}

Total mRNA was prepared using Qiazol reagent (Qiagen, Crawley, West Sussex, UK) following the manufacturer's 
instructions. A second purification step was performed immediately post extraction on the isolated total mRNA using the RNeasy Midi kit (Qiagen Inc., Valencia, CA) and each sample was treated with DNase (20 U of grade I DNase; Roche, Lewes, UK) to remove any genomic contamination following the manufacturer's instructions. With a cut-off of $150 \mathrm{bp}$, 5S rRNA and tRNAs were removed from the samples by the columns, limiting interference in downstream experiments. RNA concentration and integrity were assessed on the Nanodrop ND-1000 spectrophotometer (Nanodrop, USA) and on the Agilent 2100 bioanalyzer system (Agilent Technologies, Palo Alto, CA), using an RNA 6000 Nano LabChip kit.

\section{SMART amplification and labeling of the samples}

The extracted RNA was amplified using the SMART amplification protocol (BD Smart TM Amplification Kit, UK) and labeled with cy5 or cy3 using Klenow enzyme as described by Petalidis et al 2003 [10] with two modifications; (a) a constant number of 14 cycles was used, and (b) for the labeling step, $1 \mu \mathrm{L}$ of Cy3 or Cy5-dCTP was used with $22 \mu \mathrm{L}(250 \mathrm{ng})$ of second strand cDNA. The labeled products were purified using G50 columns, according to manufacturer's instructions (Amersham Biosciences, UK). Labeled samples were combined and precipitated for at least 2 hours at $-20^{\circ} \mathrm{C}$ with $2 \mu \mathrm{L}$ of human Cot-1 DNA, $1 \mu \mathrm{l}$ PolyA $(8 \mu \mathrm{g} / \mu \mathrm{l}), 1 \mu \mathrm{l}$ yeast tRNA $(4 \mu \mathrm{g} /$ $\mu \mathrm{l}), 10 \mu \mathrm{l} \mathrm{Na}$ acetate (3 M, pH5.2) and $250 \mu \mathrm{l} 100 \%$ ethanol.

\section{Microarray hybridization and scanning}

The labeled product was re-suspended in $40 \mu \mathrm{L}$ hybridization buffer ( $40 \%$ deionised formamide, $5 \times$ SSC, $5 \times$ Denhart's, $1 \mathrm{mM}$ Na Pyrophosphate, $50 \mathrm{mM}$ Tris Ph 7.4 and $0.1 \%$ SDS) and hybridized onto a microarray slide containing 23,000 human oligonucleotides (Illumina Inc. San Diego), printed in-house on to Codelink slides using a BioRobotics Microgrid II arrayer. After over-night hybridization of the slides at $48^{\circ} \mathrm{C}$ in a water bath, they were washed in $2 \times$ SSC, $0.1 \times$ SSC, $0.05 \%$ Tween 20 , and $0.1 \times$ SSC sequentially for $5 \mathrm{~min}$ each and scanned using an Axon 40001A scanner. Signal quantification was performed using Bluefuse software (2.0) (BlueGnome, Cambridge, UK).

\section{Analysis of the data}

Data exported from Bluefuse was analyzed using the $\mathrm{R}$ package http://www.r-project.org/ library FSPMA [11], which is based on the mixed model ANOVA library YASMA [12]. Expression values in both channels were converted to log ratios and normalized by subtracting a M/A (i.e. log ratio/log amplitude) loess fit and adjusting the within-slide scale of the data. The ANOVA model used a nested design with spot-replication (1) as the innermost effect, nested inside biological replication ( 6 for brains; 4 for lungs), with dye-swap (2) as the outermost effect. Spot-replication was considered to be a random effect and biological replication and dye-swap fixed effects. Genes were considered to be up or down regulated, if the average channel log ratios relative to the control were found to be highly significantly different from zero, using a p-value threshold of 0.05 . The p-values were calculated within the ANOVA model, using FSPMA's VARIETY option and a correction for multiple comparisons by false discovery rate. This analysis takes into consideration the variance across samples and excludes those genes with a high level of variance. We can, therefore, be confident that the smaller fold changes observed are real.

70-mer human oligonucleotide sequences from differentially expressed probe sets with a p-value $<0.01$ were used to BLAST search pig sequences in the public databases http://www.ncbi.nlm.nih.gov/BLAST/ including Unigene and ESTs [13]. For matches to Unigene clusters, Homologene was used to indicate orthology to the human probe sets. With novel ESTs, pig data were matched against the human genomic and transcript database to confirm that the best matches were to orthologous sequences. Hits were considered to be reliable if there was a putatively orthologous match of 60-70 bp, and oligonucleotides with fewer matches, in the range of 50-59 bp, were also selected if p-values were significant in this study. Probe sets that could not be verified by BLAST as described above are not reported in this paper. Analysis of the signal intensity distribution of the cross-species hybridizations for both the lung and brain experiments showed a normal distribution similar to that obtained when homologous human RNA is hybridized to the chip. The proportion of the approximately $23 \mathrm{~K}$ probes showing a signal greater than 100 signal value (i.e. above background) in the crosshybridization is 22,300 from the 22,800 probes on the chip ( $97 \%)$. The microarray data (accession number EMEXP-2376) is available through ArrayExpress.

\section{Functional annotation of gene expression data}

In order to understand the biological phenomena studied here and reduce the interpretive challenge that is posed by a long list of differentially expressed genes. Onto-Express was used to classify our lists of differentially regulated genes into functional profiles characterizing the impact of the infection on the two different tissues http://vor tex.cs.wayne.edu/ontoexpress/[14]. Initial analysis used the non-filtered dataset, i.e., all differentially regulated probe sets against the full human oligonucleotide geneset. We then looked at differentially expressed probes (p-value $<0.01$ ) identified from our microarray analysis, and statistical significance values were calculated for each category using the binomial test available in OntoExpress[15]. This makes no assumptions about those probesets with good matches to known pig sequences. 
However, only those probesets for which we could confidently assume orthology are reported in the tables in this paper. Here we present categories of gene ontology based on a maximum pairwise p-value of 0.05 for the "biological processes". To gain a better understanding of the gene interactions (pathways) involved in the disease, PathwayExpress was also applied to our data. In order to quantify the over/under representation of each category, the library composition has been taken into account in the presentation of the results.

\section{Quantitative RNA analyses using real-time PCR methodology (qRT-PCR)}

Quantitative real-time reverse transcriptase polymerase chain reaction (qRT-PCR) analysis using SYBR green and selected primers was carried out following the manufacturer's protocol (QIAGEN, QuantiTect SYBR Green RTPCR) to confirm the microarray results. All probes and primers were designed using Express Primer 3 software developed by the Whitehead Institute for Biomedical Research. The nucleotide sequences of selected genes were obtained from GenBank, and the primer information is shown in table 1. PSMD2 (primers kindly provided by Ms Gina Oliver and Dr Claire Quilter) was selected for use as the reference gene because it was previously shown to be a good control for pig brain (personal communication from Ms Gina Oliver and Dr Claire Quilter) and was also shown to be one of the most constant housekeeping genes in a human tissue study. Quantitative RT-PCR was performed on $300 \mathrm{ng}$ RNA equivalents in $25 \mu \mathrm{L} /$ reaction/well on an Icycler (Bio-Rad Laboratories Ltd, USA) $\left(50^{\circ} \mathrm{C}\right.$ for $60 \mathrm{~min} ; 95^{\circ} \mathrm{C}$ for $15 \mathrm{~min} ; 40$ cycles of $95^{\circ} \mathrm{C}$ for $15 \mathrm{sec}$, $58^{\circ} \mathrm{C}$ for $30 \mathrm{sec}$ and $72^{\circ} \mathrm{C}$ for $30 \mathrm{sec}$ ). For each gene reactions were performed in triplicate to allow statistical evaluation of the data. The average $\mathrm{Ct}$ (threshold cycle) was used for the analysis. Relative expression levels were calcu- lated by using the $2^{-(\Delta \Delta \mathrm{Ct})}$ method as previously described [16].

\section{Results \\ Microarray analysis of gene expression profiles in brain and lung}

Six brain samples and four lung samples were used for microarray hybridization and qRT-PCR, and two of the lung samples were excluded as they were found to be degraded. Table 2 shows the number of differentially expressed human probe sets initially identified in brain and lung tissues (p-value $<0.01$ and p-value $<0.05$ ). Based on BLAST analysis, those probes with putative pig gene homologues have been considered for further analysis and numbers are shown in table 2. This avoids making assumptions about other probes that detect expression changes but have weaker matches to pig ESTs. Most probes with porcine homologues remained unchanged, and few showed a reduction in transcription level by microarray analysis. For example, expression of only 4 (60-70 bp human match category) and 1 (50-59 bp human match category) were decreased in infected lung tissue ( $\mathrm{p}$-value < 0.01). In contrast, a large number of host transcripts were induced in response to wild type PRV infection (table 2). Here we identified 120 and 866 upregulated transcripts in brain and lung (p-value $<0.01$ ) with pig: human matches $\geq 60 \mathrm{bp}$, and 42 and 259 genes with matches of 50-59 bp for further gene ontology and pathway classification (table 2).

Of the transcripts with matches $\geq 60 \mathrm{bp}, 76$, corresponding to 74 unique pig gene homologues, are up-regulated in common between the two tissues and are listed in Additional file 1. Forty-four probe sets corresponding to 41 unique pig gene homologues with matches of 50-59

Table I: validation of array data by real-time PCR

\begin{tabular}{|c|c|c|c|c|c|c|}
\hline \multirow[b]{2}{*}{ Gene name } & \multirow[b]{2}{*}{ Pig homologene } & \multirow[b]{2}{*}{$\begin{array}{l}\text { Primer sequences } \\
\left(5^{\prime}-3^{\prime}\right)\end{array}$} & \multicolumn{2}{|c|}{ Microarray data } & \multicolumn{2}{|c|}{ qRT-PCR data } \\
\hline & & & $\begin{array}{c}\text { Brain } \\
\text { (n-fold change) }\end{array}$ & $\begin{array}{c}\text { Lung } \\
\text { (n-fold change) }\end{array}$ & $\begin{array}{c}\text { Brain } \\
\text { (n-fold change) }\end{array}$ & $\begin{array}{c}\text { Lung } \\
\text { (n-fold change) }\end{array}$ \\
\hline PSMD2 & Ssc. 1642 & $\begin{array}{l}\text { F: tggggagaataagcgttttg } \\
\text { R: tattcatgaccccatgatgc }\end{array}$ & Ref & Ref & Ref & Ref \\
\hline AKTI & Ssc. 29760 & $\begin{array}{l}\text { F: tgggcgacttcatccttg } \\
\text { R: tggaagtggcagtgagca }\end{array}$ & $N D^{a}$ & 1.68 & ND & 2.19 \\
\hline CDC42 & Ssc. 6687 & $\begin{array}{l}\text { F: aaagtgggtgcctgagata } \\
\text { R: ctccacatacttgacagcc }\end{array}$ & $-b$ & 2.03 & - & 7.38 \\
\hline LY96 & Ssc. 25550 & $\begin{array}{l}\text { F:cattgcacgaagagacataca } \\
\text { R: tgtattcacagtctctcccttc }\end{array}$ & 1.37 & 3.32 & 6.91 & 9.23 \\
\hline PIK3RI & Ssc.49949 & $\begin{array}{l}\text { F: cccaggaaatccaaatga } \\
\text { R: ggtcctcctccaaccttc }\end{array}$ & - & - & 0.61 & 0.45 \\
\hline SERPINEI & Ssc. 9781 & $\begin{array}{l}\text { F: ccagcagcagatccaaga } \\
\text { R: cggaacagcctgaagaagt }\end{array}$ & -1.66 & 2.36 & -0.64 & 4.28 \\
\hline
\end{tabular}

aND, not done;

$b_{-}$, not changed or absent. 
Table 2: Number of probe sets and pig gene homologues in brain and lung tissues affected by wild type PRV infection

\begin{tabular}{|c|c|c|c|c|c|c|c|c|c|}
\hline \multirow[t]{2}{*}{$p$-value } & \multirow[t]{2}{*}{ Up/down regulated } & \multicolumn{4}{|c|}{ Brain } & \multicolumn{4}{|l|}{ Lung } \\
\hline & & $\mathbf{A}$ & B & C & $D$ & $\mathbf{A}$ & B & C & $D$ \\
\hline \multirow[t]{2}{*}{$\mathrm{p}$-value $<0.01$} & down & 253 & $35(34)$ & $14(14)$ & 17 & 195 & $4(4)$ & $\mathrm{I}(\mathrm{I})$ & 11 \\
\hline & up & 528 & $132(120)$ & $44(42)$ & 115 & 2283 & $888(866)$ & $26 I(259)$ & 424 \\
\hline \multirow[t]{2}{*}{$\mathrm{p}$-value $<0.05$} & down & 588 & $77(76)$ & $26(26)$ & 43 & 1657 & $25(24)$ & $4(4)$ & 51 \\
\hline & up & 879 & $209(196)$ & $69(67)$ & 173 & 3284 & $1122(1075)$ & $357(355)$ & 545 \\
\hline
\end{tabular}

$A=$ Total number of differentially expressed human probes.

$B=$ Total number of pig Unigene matches of 60-70 basepairs (subset of verified gene or thologues).

$C=$ Total number of pig Unigene matches of 50-59 basepairs (subset of verified gene or thologues).

$\mathrm{D}=$ Total number of EST matches $>50$ basepairs with no assigned Unigene ID.

Table 3: Classes of biological processes involving up regulatedpig gene homologues $(p$-value $<0.01)$ in brain and lung tissues infected with wild type PRV.

\begin{tabular}{|c|c|c|c|c|c|}
\hline Biological Process & Library & $\begin{array}{c}\text { Brain Pig Unigene } \\
\text { Matches over } 60 \text { base- } \\
\text { pairs } \\
\text { (gene homologues) }\end{array}$ & $\begin{array}{c}\text { Brain Pig } \\
\text { Ungene } \\
\text { Matches } \\
\text { between 50- } \\
\text { 59b base-pairs (gene } \\
\text { homologues) }\end{array}$ & $\begin{array}{c}\text { Lung Pig Unigene } \\
\text { Matches over } 60 \text { base- } \\
\text { pairs } \\
\text { (gene homologues) }\end{array}$ & $\begin{array}{c}\text { Lung Pig Unigene } \\
\text { Matches between 50- } \\
\text { 59b base-pairs } \\
\text { (gene homologues) }\end{array}$ \\
\hline Apoptosis & 230 & $3^{*}$ & 0 & $30 *$ & 4 \\
\hline $\begin{array}{l}\text { Biological function } \\
\text { unknown }\end{array}$ & 472 & 4 & 0 & 31 & 10 \\
\hline Cation transport & 139 & $2^{*}$ & $3^{*}$ & 0 & 2 \\
\hline Cell adhesion & 429 & $8^{*}$ & $5^{*}$ & 11 & 4 \\
\hline Cell cycle & 303 & 3 & 0 & $31 *$ & 3 \\
\hline Cell differentiation & 230 & $4^{*}$ & $I^{*}$ & 7 & 2 \\
\hline Immune response & 255 & 0 & 0 & 7 & 3 \\
\hline $\begin{array}{l}\text { Intracellular protein } \\
\text { transport }\end{array}$ & 135 & $5^{*}$ & 0 & $16^{*}$ & $5^{*}$ \\
\hline $\begin{array}{l}\text { Intracellular signaling } \\
\text { cascade }\end{array}$ & 285 & $4^{*}$ & 0 & 14 & 3 \\
\hline Ion transport & 304 & $5^{*}$ & 1 & 6 & 4 \\
\hline Metabolism & 280 & $3^{*}$ & 3 & $15^{*}$ & $9 *$ \\
\hline $\begin{array}{l}\text { Nervous system } \\
\text { development }\end{array}$ & 239 & $9 *$ & $3^{*}$ & 9 & 3 \\
\hline $\begin{array}{l}\text { Protein amino acid } \\
\text { dephosphorylation }\end{array}$ & 108 & I & $2^{*}$ & $14 *$ & I \\
\hline $\begin{array}{l}\text { Protein amino acid } \\
\text { phosphorylation }\end{array}$ & 412 & I & $2^{*}$ & 29 & 7 \\
\hline Protein folding & 165 & $4^{*}$ & 0 & $27^{*}$ & $5^{*}$ \\
\hline Protein transport & 217 & 2 & $2^{*}$ & $33^{*}$ & 4 \\
\hline Proton transport & 47 & I* & $2^{*}$ & 3 & $7 *$ \\
\hline $\begin{array}{l}\text { Regulation of } \\
\text { progression through cell } \\
\text { cycle }\end{array}$ & 215 & 2 & $2^{*}$ & $20 *$ & 4 \\
\hline $\begin{array}{l}\text { Regulation of } \\
\text { transcription, DNA } \\
\text { dependent }\end{array}$ & 1285 & 9 & 2 & 73 & 7 \\
\hline Signal transduction & 1110 & 6 & 1 & 40 & 6 \\
\hline Synaptic transmission & 164 & $4^{*}$ & $4^{*}$ & 5 & I \\
\hline Transcription & 945 & 7 & $\mathrm{I}$ & 63 & 7 \\
\hline Ubiquitin cycle & 217 & I & 0 & $30 *$ & 4 \\
\hline
\end{tabular}

* Biological processes with at least two times the expected number of genes (calculated from the library composition). 
bp also displayed increased expression in both tissues after infection by wild type PRV (Additional file 1).

\section{Gene Ontology and bioinformatics analysis}

To characterize the sets of functionally related genes that are differentially expressed between the infected and uninfected group, we used the Onto- Express tool to classify up-regulated genes in each tissue according to their biological process. Table 3 summarizes the largest classes identified on the basis of biological process. Twelve defined biological processes with matches $\geq 60 \mathrm{bp}$, and 10 with matches of 50-59 bp, are observed in brain at least two fold more often than expected. In comparison, 9 processes with matches $\geq 60 \mathrm{bp}$, and only 4 with matches of 50-59 bp are over-represented in lung, although the total number of up-regulated genes in lung is more than that in brain tissue (table 2).

\section{Pathways affected by wild- type PRV infection in brain and lung}

One indication that the observed transcript differences (pvalue $<0.01$ ) may have biological relevance is that sets of genes in known pathways show coordinated regulation. Accordingly, the functionally classified genes were mapped to known cellular pathways. Fifteen pathways with at least five times the expected number of genes (matches $\geq 60 \mathrm{bp}$ ) have been highlighted with pathwayexpress in the infected brain. Interestingly, most of them belong to neurodegenerative disorders, nervous system and immune system pathways. Twelve pathways (including the calcium signaling pathway, the phosphatidylinositol signaling system and the TGF $\beta$ signaling pathway) with at least five times the expected number of genes (matches of 50-59 bp) were also highlighted in the infected brain. However only 4 pathways (ubiquitin mediated proteolysis and prion disease, matches $\geq 60 \mathrm{bp}$; ALS and mTOR signaling pathway, matches of 50-59 bp) showed at least five times the expected number of genes in the infected lung (table 4). Interestingly, ubiquitination of PRV glycoproteins for vaccination has been shown to be related to decreased cellular immune responses following wild type infection. Additional file 2 lists the details of genes that were assigned to cellular processes, environmental information processes and human disease pathways.

Ten genes up-regulated in both tissues by wild-type PRV infection segregated into known pathways (Additional file 2). Most of them are involved in multiple pathways, such as SPP1 in the immune response pathway, the ECMreceptor interaction and focal adhesion pathway, and FOS and CDC42 in the T cell receptor signaling pathway and MAPK signaling pathway. Moreover, it is also interesting to note that a few genes such as SERPINE1 and LCP2 respond differently in the two tissues studied, and while some of the pathways responding to the infection are ubiquitous, others appear to be tissue specific (Additional file 2).

\section{qRT-PCR analysis for validation of microarray results}

In order to verify the data obtained in the microarray experiment, we confirmed the expression profile of 5 selected genes with different patterns of expression: LY96 is differentially expressed in the same direction in both tissues; SERPINE1 is down-regulated in the brain but up-regulated in the lung after infection; CDC42 and AKT1 are significantly up-regulated in lung tissue only, and PIK3R1 is not significantly differentially expressed. Results from real-time quantitative RT-PCR confirmed the direction of expression (up or down-regulated) obtained by microarray analysis in the 5 genes tested (table 1). The magnitude of the fold change is not the same. This is most probably due to the fact that the array analysis is based on a crossspecies hybridization whereas the RT-PCR has been performed using species homologous primers. It is likely that the RT-PCR analysis reflects more accurately the fold change in expression.

\section{Discussion}

The virus replication cycle involves a series of host-virus interactive processes causing changes in expression of cellular genes, and an infected host activates both innate and adaptive immune responses to eliminate the invading virus [17]. The pig is an ideal animal model for studying human diseases, so the identification of pig model biomarkers for viral diseases is an important step towards identification of human counterparts. The identification of biomarkers has already been proposed as a way to create new diagnostic tools for specific microbial infection $[18,19]$.

Previous studies have shown the value of using cross-species hybridization [20]. Here, using the Illumina human oligonucleotide Refset in a cross-species study we identified hundreds of probes with expression levels that were altered in brain and lung following wild type PRV infection of young piglets, which typically have more severe clinical manifestations than the adult. In adult pigs one observes mainly, or exclusively, the respiratory symptoms, whereas in piglets and rodent hosts there is invariably invasion of the central nervous system (CNS) [21,22]: piglets exhibit signs in the form of tremor, trembling and incoordination. Thus piglets permit the potential identification of a wider spectrum of genes involved in the disease processes in different tissues.

Classification of the genes that are differentially expressed in piglet brain into functional groups(Additional file 2) revealed that several genes are also implicated in human neurodegenerative disorders. These include genes in the 
Table 4: Cellular Pathways involving up-regulated ( $p$-value $<0.01)$ pig gene homologues in brain and lung tissues infected with wild type PRV.

\begin{tabular}{|c|c|c|c|c|c|}
\hline Pathway Name & Library & $\begin{array}{c}\text { Brain } \\
\text { Pig Unigene Matches } \\
\text { over } 60 \text { base-pairs (gene } \\
\text { homologues) }\end{array}$ & $\begin{array}{c}\text { Brain } \\
\text { Pig Unigene } \\
\text { Matches } \\
\text { between 50- } \\
59 \mathrm{~b} \text { base- } \\
\text { pairs (gene } \\
\text { homologues) }\end{array}$ & $\begin{array}{c}\text { Lung Pig Unigene } \\
\text { Matches over } 60 \text { base- } \\
\text { pairs (gene homologues) }\end{array}$ & $\begin{array}{c}\text { Lung } \\
\text { Pig Unigene Matches } \\
\text { between 50-59b base- } \\
\text { pairs (gene homologues) }\end{array}$ \\
\hline
\end{tabular}

\begin{tabular}{|c|c|c|c|c|}
\hline \multicolumn{5}{|l|}{ Behavior } \\
\hline Circadian rhythm & 17 & 0 & 0 & 1 \\
\hline \multicolumn{5}{|l|}{ Cancers } \\
\hline Colorectal cancer & 73 & 2* & 0 & 9 \\
\hline \multicolumn{5}{|l|}{ Cell Communication } \\
\hline Adherens junction & 72 & $2 *$ & 0 & 9 \\
\hline Focal adhesion & 187 & 4 & I & 11 \\
\hline Gap junction & 91 & $3 *$ & 0 & 5 \\
\hline Tight junction & 106 & 2 & 0 & 13 \\
\hline \multicolumn{5}{|l|}{ Cell Growth and Death } \\
\hline Apoptosis & 81 & 0 & 0 & 3 \\
\hline Cell cycle & 105 & I & $I^{*}$ & 12 \\
\hline \multicolumn{5}{|l|}{ Cell Motility } \\
\hline $\begin{array}{l}\text { Regulation of actin } \\
\text { cytoskeleton }\end{array}$ & 195 & $6 *$ & 0 & 12 \\
\hline \multicolumn{5}{|l|}{ Development } \\
\hline Axon guidance & 119 & 2 & 1 & 7 \\
\hline \multicolumn{5}{|l|}{ Endocrine System } \\
\hline $\begin{array}{l}\text { Adipocytokine } \\
\text { signaling pathway }\end{array}$ & 68 & I & 0 & 2 \\
\hline $\begin{array}{l}\text { GnRH signaling } \\
\text { pathway }\end{array}$ & 94 & $3^{*}$ & $2^{*}$ & 6 \\
\hline $\begin{array}{l}\text { Insulin signaling } \\
\text { pathway }\end{array}$ & 125 & 2 & 1 & 8 \\
\hline \multicolumn{5}{|l|}{$\begin{array}{l}\text { Folding, Sorting and } \\
\text { Degradation }\end{array}$} \\
\hline $\begin{array}{l}\text { Regulation of } \\
\text { autophagy }\end{array}$ & 24 & 0 & 0 & 2 \\
\hline $\begin{array}{l}\text { SNARE interactions in } \\
\text { vesicular transport }\end{array}$ & 28 & 0 & $I^{*}$ & 3 \\
\hline $\begin{array}{l}\text { Ubiquitin mediated } \\
\text { proteolysis }\end{array}$ & 41 & 0 & $I^{*}$ & $\mathrm{II} *$ \\
\hline \multicolumn{5}{|l|}{ Immune System } \\
\hline $\begin{array}{l}\text { Antigen processing and } \\
\text { presentation }\end{array}$ & 80 & 0 & 0 & 3 \\
\hline $\begin{array}{l}\text { B cell receptor } \\
\text { signaling pathway }\end{array}$ & 61 & $2 *$ & 0 & 6 \\
\hline $\begin{array}{l}\text { Complement and } \\
\text { coagulation cascades }\end{array}$ & 60 & 0 & 0 & I \\
\hline $\begin{array}{l}\text { Fc epsilon RI signaling } \\
\text { pathway }\end{array}$ & 73 & $2 *$ & 0 & 4 \\
\hline $\begin{array}{l}\text { Leukocyte } \\
\text { transendothelial } \\
\text { migration }\end{array}$ & 111 & I & 0 & 6 \\
\hline $\begin{array}{l}\text { Natural killer cell } \\
\text { mediated cytotoxicity }\end{array}$ & 119 & 2 & 0 & 4 \\
\hline $\begin{array}{l}\mathrm{T} \text { cell receptor } \\
\text { signaling pathway }\end{array}$ & 87 & $3 *$ & 0 & 5 \\
\hline $\begin{array}{l}\text { Toll-like receptor } \\
\text { signaling pathway }\end{array}$ & 87 & 1 & 0 & 6 \\
\hline \multicolumn{5}{|l|}{ Infectious Diseases } \\
\hline $\begin{array}{l}\text { Epithelial cell signaling } \\
\text { in Helicobacter pylori } \\
\text { infection }\end{array}$ & 45 & I & 0 & 5 \\
\hline \multicolumn{5}{|l|}{ Metabolic Disorders } \\
\hline $\begin{array}{l}\text { Type I diabetes } \\
\text { mellitus }\end{array}$ & 42 & I & $I^{*}$ & 2 \\
\hline \multicolumn{5}{|l|}{ Nervous System } \\
\hline Long-term depression & 74 & $2 *$ & 0 & 5 \\
\hline
\end{tabular}


Table 4: Cellular Pathways involving up-regulated ( $p$-value $<0.01$ ) pig gene homologues in brain and lung tissues infected with wild type PRV. (Continued)

\begin{tabular}{|c|c|c|c|c|c|}
\hline $\begin{array}{l}\text { Long-term } \\
\text { potentiation }\end{array}$ & 65 & $2^{*}$ & $2^{*}$ & 5 & 3 \\
\hline \multicolumn{6}{|l|}{$\begin{array}{l}\text { Neurodegenerative } \\
\text { disorders }\end{array}$} \\
\hline $\begin{array}{l}\text { Neurodegenerative } \\
\text { disorders }\end{array}$ & 33 & $2^{*}$ & $I^{*}$ & 0 & 1 \\
\hline Alzheimer's disease & 18 & 0 & 0 & 2 & 0 \\
\hline $\begin{array}{l}\text { Amyotrophic lateral } \\
\text { sclerosis (ALS) }\end{array}$ & 17 & $3^{*}$ & 0 & 0 & $2 *$ \\
\hline $\begin{array}{l}\text { Dentatorubropallidolu } \\
\text { ysian atrophy (DRPLA) }\end{array}$ & 12 & 0 & 0 & I & 0 \\
\hline Huntington's disease & 26 & $2^{*}$ & I* & 4 & 0 \\
\hline Parkinson's disease & 15 & $I^{*}$ & 0 & 0 & 0 \\
\hline Prion disease & 10 & $I^{*}$ & 0 & $3^{*}$ & 0 \\
\hline \multicolumn{6}{|l|}{ Sensory System } \\
\hline Olfactory transduction & 30 & 0 & $2^{*}$ & 2 & 0 \\
\hline Taste transduction & 51 & I & 0 & I & 0 \\
\hline \multicolumn{6}{|l|}{ Signal Transduction } \\
\hline $\begin{array}{l}\text { Calcium signaling } \\
\text { pathway }\end{array}$ & 173 & 0 & $4^{*}$ & 3 & 3 \\
\hline $\begin{array}{l}\text { Hedgehog signaling } \\
\text { pathway }\end{array}$ & 54 & 0 & 0 & 3 & 0 \\
\hline $\begin{array}{l}\text { Jak-STAT signaling } \\
\text { pathway }\end{array}$ & 147 & 0 & 0 & 6 & 2 \\
\hline $\begin{array}{l}\text { MAPK signaling } \\
\text { pathway }\end{array}$ & 267 & 5 & 2 & 18 & 7 \\
\hline $\begin{array}{l}\text { mTOR signaling } \\
\text { pathway }\end{array}$ & 44 & 0 & 0 & 4 & $3 *$ \\
\hline $\begin{array}{l}\text { Notch signaling } \\
\text { pathway }\end{array}$ & 39 & 0 & 0 & I & 0 \\
\hline $\begin{array}{l}\text { Phosphatidylinositol } \\
\text { signaling system }\end{array}$ & 77 & 0 & $I^{*}$ & 0 & 0 \\
\hline $\begin{array}{l}\text { TGF-beta signaling } \\
\text { pathway }\end{array}$ & 70 & I & $I^{*}$ & II & 0 \\
\hline $\begin{array}{l}\text { VEGF signaling } \\
\text { pathway }\end{array}$ & 68 & 3 & 0 & 5 & 2 \\
\hline Wnt signaling pathway & 138 & 0 & I & 12 & 2 \\
\hline \multicolumn{6}{|l|}{$\begin{array}{l}\text { Signaling Molecules and } \\
\text { Interaction }\end{array}$} \\
\hline $\begin{array}{l}\text { Cell adhesion } \\
\text { molecules (CAMs) }\end{array}$ & 123 & 2 & I & 3 & 2 \\
\hline $\begin{array}{l}\text { Cytokine-cytokine } \\
\text { receptor interaction }\end{array}$ & 242 & 0 & 0 & 3 & 2 \\
\hline $\begin{array}{l}\text { ECM-receptor } \\
\text { interaction }\end{array}$ & 85 & 1 & 0 & 3 & 2 \\
\hline $\begin{array}{l}\text { Neuroactive ligand- } \\
\text { receptor interaction }\end{array}$ & 275 & 1 & 0 & I & 0 \\
\hline
\end{tabular}

* Cellular pathways with at least five times the expected number of genes (calculated from the library composition).

pathways for amyotrophic lateral sclerosis (NEF3, NEFL, NEFH), Huntington's disease (CALM3, CLTC, CLTB), neurodegenerative disorders (APLP1, NEFH, FBXW7), Parkinson's disease (GPR37) and prion disease (APLP1, NFE2L2). It is not known if these transcriptional changes are primary or secondary effects of the PRV infection.

Several members of the immune response pathways (eg. the B cell receptor signaling pathway, the Fc epsilon RI signaling pathway, natural killer cell mediated cytotoxicity and the T cell receptor signaling pathway) were also transcriptionally regulated by PRV infection in brain. This is in agreement with the results from PRV or HSV-1 infection in primary cultures of rat embryonic fibroblasts [5]. In addition, similar changes to immune response pathway (e.g. antigen processing and presentation, complement and coagulation cascades), cell differentiation and metabolism pathway genes have been described in the host following PRV infection in rat CNS [6]. Our experiment not only identified pathways, but also several genes in common with these previous studies: FOS and LCP2, both involved in T cell receptor signalling pathways; the TGF $\beta$ signal transduction pathway components ID4 and THBS4, highlighted in the study of PRV infection of primary cultures of rat embryonic fibroblasts $[5,6]$; and SERPINE-1, identified in both earlier rat studies. These genes 
may be potential diagnostic and therapeutic targets for viral encephalitis and other neurodegenerative or neuroinflammatory diseases.

Several genes of the TGF $\beta$ pathway were also identified here in the infected lung tissue (e.g. PPP2CA, PPP2CB, ID2, ID3 and ID4). After PRV infection, most older swine exhibit signs of respiratory disease, and the study of the lung is therefore important for understanding what genes may be involved in the disease process. We identified 1130 differentially expressed probes as a result of wildtype PRV infection; this is 5 times higher than in the brain. The lung may be more transcriptionally active, or have a more pronounced immune response that might involve more immune cell types than the brain. In addition, we have identified 5 possible viral receptors, normally necessary for the spread of virus between cells, up-regulated in the infected lung: HveC (PVRL1), PVRL3, HveD (PVR, CD155), HS3ST4 and HS3ST5 [23,24]. Finally, a number of members of the TNF receptor family, usually involved in apoptosis, were identified (TNFRSF10, 21, 25, 9, 17, 8, $1 \alpha$ ). This apoptotic pathway was also described in the study of HSV infection of glial cell types [25]. However, the result is interesting as the family member TNFRSF14 has been shown to be involved in some cases of viral entry, but we do not know whether these other family members are involved in viral entry and cell fusion, or only have a downstream role.

Numerous other genes involved in cellular proliferation (YWHAB, BUB1, PCNA, GADD45, MCM7, CDK4, CDK7) and apoptosis (PRKACA, PDCD8, AKT1, PPP3CA), were identified. These pathways were previously described following PRV and HSV infection in several models [5,25] and might reflect the proliferation of immune cells. A number of other genes differentially expressed in the lung, such as HSPD1, HSPB2, SERPINE-1, are in common with human and mouse models infected by HSV-1 $[5,26]$.

Recently, Flori et al [27] have published a time course transcription profiling study (based on the Qiagen 8541 gene porcine oligonucleotide array and a 1789 porcine and PRV cDNA array) investigating both the PRV transcriptome and the host transcriptome responses of PK15 (porcine kidney) cells in culture. This study reports the early down-regulation of many cellular genes in contrast to the data in this paper. This difference most probably arises from the artificial cell culture study where there is a homogeneous cell population, whereas our present study is an in vivo investigation of complex tissues. It is entirely possible that minor tissue cell types exhibit down-regulation of many of the same genes, however, their contribution to the overall signal renders these changes undetectable. This may also explain the differences in gene expression changes for shared genes between lung and brain. In general, fold changes are lower in brain which probably reflects the complexity of cell types in the tissue, not all of which may respond equally to infection. Nevertheless, it is clear that the Flori et al. study has also observed changes in gene expression in the main categories of cellular functions described in this paper; most notably genes involved in immune responses and cell proliferation and apoptosis.

Genetic differences have been reported in the susceptibility to PRV between European Large White and Chinese Meishan pigs, with differences in cell-mediated and humoral immunity, as well as the outward clinical signs in young pigs [28]. In this study we identified several differentially expressed genes located at or close to the QTL regions previously reported. Two genes (CD36 and NPL) up-regulated in the infected brain and lung are located near the SW749 marker, which is associated with changes in body temperature and neurological signs. ETA1 (alias SPP1), which is involved in the recruitment of T-lymphocytes $[29,30]$, was up-regulated in both tissues after natural PRV infection, and is linked to the QTL region of chromosome 8. One of the PRV receptors, PVRL3, which is differentially expressed in infected lung, is linked to a QTL on chromosome 13. CLDN7, which is involved with cell communication, was down-regulated in the infected brain and is linked to a QTL on chromosome 13 associated with neurological signs.

\section{Conclusion}

By combining the array data presented here with the information from the previous QTL study, it may be possible to identify the best candidates for the clinical features and increased resistance to PRV infection. In addition, further studies and functional analysis of these candidates will broaden the scientific understanding of PRV infection, provide biomarkers to use as diagnostic tools, and may also lead to the development of novel antiviral treatments and/or the application of marker assisted selection for disease resistance.

\section{Abbreviations}

$\mu \mathrm{L}$ : microliter(s); AKT1: v-akt murine thymoma viral oncogene homolog 1; ALS: amyotrophic lateral sclerosis; APLP1: amyloid beta (A4) precursor-like protein 1; BHV1: bovine herpesvirus 1; bp: basepair(s); BUB1: budding uninhibited by benzimidazoles 1 ; CALM3: calmodulin 3; CDC42: cell division cycle 42; CDK4: cyclin-dependent kinase 4; CDK7: cyclin-dependent kinase 7; cDNA: complementary deoxyribonucleic acid; CLTB: clathrin light chain; CLTC: clathrin heavy chain; CNS: central nervous system; Ct: threshold cycle; DNA: deoxyribonucleic acid; EST: expressed sequence tag; FBXW7: F-box and WD repeat domain containing 7; FOS: v-fos FBJ murine osteosarcoma viral oncogene homolog; GADD45: growth 
arrest and DNA-damage-inducible alpha; GPR37: G protein-coupled receptor 37; h: hour; HS3ST4: heparan sulfate (glucosamine) 3-O-sulfotransferase 5; HS3ST5: heparan sulfate (glucosamine) 3-O-sulfotransferase 5; HSPB2: heat shock $27 \mathrm{kDa}$ protein 2; HSPD1: heat shock $60 \mathrm{kDa}$ protein 1; HveC (PVRL1): herpesvirus entry mediator C (poliovirus receptor-related 1); HveD (PVR): herpesvirus entry mediator D (poliovirus receptor); ID2: inhibitor of DNA binding 2; ID3: inhibitor of DNA binding 3; ID4: inhibitor of DNA binding 4; LCP2: lymphocyte cytosolic protein 2; MAPK: mitogen-activated protein kinase; MCM7: minichromosome maintenance complex component 7; mRNA: messenger ribonucleic acid; mTOR: mechanistic target of rapamycin; Na: sodium; NEF3: neurofilament, medium polypeptide; NEFH: neurofilament, heavy polypeptide; NEFL: neurofilament, light polypeptide; NFE2L2: nuclear factor (erythroid-derived 2)-like 2; ng: nanogram(s); PCNA: proliferating cell nuclear antigen; PCR: polymerase chain reaction; PDCD8: programmed cell death 8; PIK3R1: phosphoinositide-3kinase regulatory subunit 1; PPP2CA: protein phosphatase 2 catalytic subunit alpha isoform; PPP2CB: protein phosphatase 2 catalytic subunit beta isoform; PPP3CA: protein phosphatase 3 catalytic subunit alpha isoform; PRKACA: protein kinase, cAMP-dependent, catalytic, alpha; PRRS: porcine reproductive and respiratory syndrome; PRV: pseudorabies virus; PSMD2: 26S proteasome non-ATPase regulatory subunit 2; PVRL3: poliovirus receptor-related 3; qRT: quantitative real time; QTL: quantitative trait locus; rRNA: ribosomal ribonucleic acid; SERPINE1: plasminogen activator inhibitor, type I; SPP1: secreted phosphoprotein 1 ; TGF $\beta$ : transforming growth factor, beta; THBS4: thrombospondin 4; TNFRSF: tumor necrosis factor receptor superfamily; tRNA: transfer ribonucleic acid; YWHAB: tyrosine 3-monooxygenase/tryptophan 5-monooxygenase activation protein, beta polypeptide.

\section{Authors' contributions}

JFY, SJZ and OJ performed the microarray experiments. RAF and OEC contributed towards the data analysis. GHZ carried out animal experiments and sample collection. CAS and NAA contributed intellectually to the study, and to manuscript preparation. All authors have read and approved the final manuscript.

\section{Additional material}

\section{Additional file 1}

Pig gene homologues up-regulated in both tissues (brain and lung) by wild type PRV infection. The data provided represent the Pig gene homologues up-regulated in both tissues (brain and lung) by wild type PRV infection

Click here for file

[http://www.biomedcentral.com/content/supplementary/14712180-9-246-S1.DOC]

\section{Additional file 2}

Pathways of pig gene homologues regulated in brain and lung tissues by wild type PRV infection. Data represents the pathways of pig gene homologues regulated in brain and lung tissues by wild type PRV infection.

Click here for file

[http://www.biomedcentral.com/content/supplementary/14712180-9-246-S2.DOC]

\section{Acknowledgements}

We thank Anthony Brown, Peter Ellis, Gina Oliver, Claire Quilter, Junlong Zhao and Rui Zhou for their skilled technical assistance. Financial assistance from the 863 High Technology and Development Project of China (2006AA I0Z1 95, 2007AA I0ZI52), Chinese projects (2006BADI4B08-02, 2006BAD04A02-II), Hubei project (2006CA023), Wuhan project (20067003 I I I-06) and National Project of China (04EFN2 I 4200206) is greatly appreciated.

\section{References}

I. Pomeranz LE, Reynolds AE, Hengartner CJ: Molecular biology of pseudorabies virus: impact on neurovirology and veterinary medicine. Microbiol Mol Biol Rev 2005, 69(3):462-500.

2. Roizman B, Pellett PE: The family Herpesviridae: a brief introduction. In Fields virology Volume 2. 4th edition. Edited by: Knipe DM, Howley PM. Philadelphia, Pa: Lippincott Williams \& Wilkins; 2001:2381-2397.

3. Taddeo B, Esclatine A, Roizman B: The patterns of accumulation of cellular RNAs in cells infected with a wild-type and a mutant herpes simplex virus I lacking the virion host shutoff gene. Proceedings of the National Academy of Sciences of the United States of America 2002, 99(26): 1703 I- 17036.

4. Jones JO, Arvin AM: Microarray analysis of host cell gene transcription in response to varicella-zoster virus infection of human $T$ cells and fibroblasts in vitro and SCIDhu skin xenografts in vivo. Journal of virology 2003, 77(2): $1268-1280$.

5. Ray N, Enquist LW: Transcriptional response of a common permissive cell type to infection by two diverse alphaherpesviruses. Journal of virology 2004, 78(7):3489-350I.

6. Paulus C, Sollars PJ, Pickard GE, Enquist LW: Transcriptome signature of virulent and attenuated pseudorabies virus-infected rodent brain. Journal of virology 2006, 80(4): 1773-1786.

7. Poletto R, Siegford JM, Steibel JP, Coussens PM, Zanella AJ: Investigation of changes in global gene expression in the frontal cortex of early-weaned and socially isolated piglets using microarray and quantitative real-time RT-PCR. Brain research 2006, 1068(I):7-15.

8. Brittle EE, Reynolds AE, Enquist LW: Two modes of pseudorabies virus neuroinvasion and lethality in mice. Journal of virology 2004, 78(23): | $295|-| 2963$.

9. Allison DB, Cui X, Page GP, Sabripour M: Microarray data analysis: from disarray to consolidation and consensus. Nature reviews 2006, 7(I):55-65.

10. Petalidis L, Bhattacharyya S, Morris GA, Collins VP, Freeman TC, Lyons PA: Global amplification of mRNA by template-switching PCR: linearity and application to microarray analysis. Nucleic acids research 2003, 3 I (22): el 42.

II. Sykacek P, Furlong RA, Micklem G: A friendly statistics package for microarray analysis. Bioinformatics (Oxford, England) 2005, 2 I (2I):4069-4070.

12. Wernisch L, Kendall SL, Soneji S, Wietzorrek A, Parish T, Hinds J, Butcher PD, Stoker NG: Analysis of whole-genome microarray replicates using mixed models. Bioinformatics (Oxford, England) 2003, I (I):53-6I.

13. Altschul SF, Gish W, Miller W, Myers EW, Lipman DJ: Basic local alignment search tool. Journal of molecular biology 1990, 215(3):403-410.

14. Khatri P, Draghici S, Ostermeier GC, Krawetz SA: Profiling gene expression using onto-express. Genomics 2002, 79(2):266-270. 
15. Draghici S, Khatri P, Martins RP, Ostermeier GC, Krawetz SA: Global functional profiling of gene expression. Genomics 2003, 8 I(2):98-104.

16. Livak KJ, Schmittgen TD: Analysis of relative gene expression data using real-time quantitative PCR and the 2(-Delta Delta C(T)) Method. Methods (San Diego, Calif) 200I, 25(4):402-408.

17. Lee C, Bachand A, Murtaugh MP, Yoo D: Differential host cell gene expression regulated by the porcine reproductive and respiratory syndrome virus GP4 and GP5 glycoproteins. Veterinary immunology and immunopathology 2004, 102(3):189-198.

18. Nau GJ, Richmond JF, Schlesinger A, Jennings EG, Lander ES, Young RA: Human macrophage activation programs induced by bacterial pathogens. Proceedings of the National Academy of Sciences of the United States of America 2002, 99(3): $1503-1508$.

19. Chan VL: Bacterial genomes and infectious diseases. Pediatric research 2003, 54(I): $1-7$.

20. Shah G, Azizian M, Bruch D, Mehta R, Kittur D: Cross-species comparison of gene expression between human and porcine tissue, using single microarray platform--preliminary results. Clinical transplantation 2004, I 8(Suppl I 2):76-80

21. McEwen BS, Biron CA, Brunson KW, Bulloch K, Chambers WH, Dhabhar FS, Goldfarb RH, Kitson RP, Miller AH, Spencer RL, et al:: The role of adrenocorticoids as modulators of immune function in health and disease: neural, endocrine and immune interactions. Brain Res Brain Res Rev 1997, 23(I-2):79-133.

22. Rassnick S, Enquist LW, Sved AF, Card JP: Pseudorabies virusinduced leukocyte trafficking into the rat central nervous system. Journal of virology I998, 72(I I):918I-9191.

23. Campadelli-Fiume G, Cocchi F, Menotti L, Lopez M: The novel receptors that mediate the entry of herpes simplex viruses and animal alphaherpesviruses into cells. Reviews in medical virology 2000, I0(5):305-319.

24. Spear PG, Eisenberg RJ, Cohen GH: Three classes of cell surface receptors for alphaherpesvirus entry. Virology 2000, 275(I):I-8.

25. Aravalli RN, Hu S, Rowen TN, Gekker G, Lokensgard JR: Differential apoptotic signaling in primary glial cells infected with herpes simplex virus I. Journal of neurovirology 2006 I 2(6):50I-5IO.

26. Higaki S, Deai T, Fukuda M, Shimomura Y: Microarray analysis in the HSV-I latently infected mouse trigeminal ganglion. Cornea 2004, 23(8 Suppl):S42-47.

27. Flori L, Rogel-Gaillard C, Cochet M, Lemonnier G, Hugot K, Chardon P, Robin S, Lefevre F: Transcriptomic analysis of the dialogue between Pseudorabies virus and porcine epithelial cells during infection. $B M C$ genomics 2008, 9:123.

28. Reiner G, Melchinger E, Kramarova M, Pfaff E, Buttner M, Saalmuller $A$, Geldermann $\mathrm{H}$ : Detection of quantitative trait loci for resistance/susceptibility to pseudorabies virus in swine. The Journal of general virology 2002, 83(Pt I): 167-I72.

29. Patarca R, Freeman G], Singh RP, Wei FY, Durfee T, Blattner F, Regnier DC, Kozak CA, Mock BA, Morse HC, et al.: Structural and functional studies of the early $T$ lymphocyte activation I (Eta-I) gene. Definition of a novel T cell-dependent response associated with genetic resistance to bacterial infection. The Journal of experimental medicine 1989, I 70(1):145-161.

30. Lebedev AA, Krause MH, Isidro AL, Vagin AA, Orlova EV, Turner I Dodson EJ, Tavares P, Antson AA: Structural framework for DNA translocation via the viral portal protein. The EMBO journal 2007, 26(7): 1984-1994.
Publish with Biomed Central and every scientist can read your work free of charge

"BioMed Central will be the most significant development for disseminating the results of biomedical research in our lifetime. "

Sir Paul Nurse, Cancer Research UK

Your research papers will be:

- available free of charge to the entire biomedical community

- peer reviewed and published immediately upon acceptance

- cited in PubMed and archived on PubMed Central

- yours - you keep the copyright

Submit your manuscript here:

http://www.biomedcentral.com/info/publishing_adv.asp
BioMedcentral 